\title{
Otolaryngological findings in mucopolysaccharidosis
}

\author{
Mukopolisakkaridoz hastalarındaki otolarengolojik bulgular \\ Cemal Cingi', Nuray Bayar Muluk², Deniz Hanci³, Ethem Şahin ${ }^{4}$, Mustafa Acar ${ }^{5}$ \\ ${ }^{1}$ Department of Otorhinolaryngology, Faculty of Medicine, Eskişehir Osmangazi University, Eskişehir, Turkey \\ ${ }^{2}$ Department of Otorbinolaryngology, Faculty of Medicine, Kirıkkale University, Kirıkkale, Turkey \\ ${ }^{3}$ ENT Department, Liv Hospital, Istanbul, Turkey \\ ${ }^{4}$ ENT Clinic, Bayındır Göztepe Hospital, Istanbul, Turkey
}

\begin{abstract}
In this review paper, we reported otolaryngological problems in patients with mucopolysaccharidoses (MPSs). Mucopolysaccharidoses are a group of lysosomal storage diseases, each of which is produced by an inherited deficiency of an enzyme involved in the degradation of acid mucopolysaccharides, now called glycosaminoglycans (GAGs). The mucopolysaccharidoses consist of a group of 7 metabolic disorders, known as mucopolysaccharidoses types I-VII. In all groups, there are clinical and otolaryngological manifestations. In MPS patients, upper airway obstruction, obstructive sleep apnea, restriction of mouth opening, middle ear effusion, hearing and breathing problems, etc. are reported as common otolaryngological findings. Increasing awareness of MPS's among ENT doctors will be a life saving attempt for MPS suspected patients who admit an ENT doctor rather than a pediatrician. In MPS patients, tracheotomy may be difficult due to short neck. Due to mouth opening restriction, patients should be evaluated carefully before tonsillectomy and adenoidectomy operations. Airway problems must be evaluated before anesthesia. All ENT doctors should be noticed to be aware of these problems.
\end{abstract}

Keywords: Mucopolysaccharidoses (MPSs), lysosomal storage diseases, short neck, mouth opening restriction, airway problems.

Mucopolysaccharidoses (MPSs) are a group of lysosomal storage diseases, each of which is produced by an inherited deficiency of an enzyme involved in the degradation of acid mucopolysaccharides, called glycosaminoglycans (GAGs). ${ }^{[1,2]}$ Glycosaminoglycan is an important constituent of the extracellular matrix, joint fluid, and connective tissue throughout the body. Progressive accumulation

\section{Özet}

Bu derleme makalede MPS hastalarındaki otolarengolojik sorunları raporladık. Mukopolisakkaridozlar (MPS'ler) her biri mukopolisakkaritlerin parçalanmasında rol alan ve şimdilerde glikozaminoglikanlar denilen (GAG'ler) kalıtsal bir enzim eksikliği nedeniyle oluşan bir lizozom depo hastalıkları grubudur. Mukopolisakkaridozlar, mukopolisakkaridoz tip 1-VII diye bilinen 7 metabolizma hastalığı grubunu oluştururlar. Grupların tümünde klinik ve otolaringolojik belirtiler görülür. Mukopolisakkaridoz hastalarında sık görülen otolarengolojik bulgular olarak üst hava yolu obstrüksiyonu, obstrüktif uyku apnesi, ağız açmanın kısıtlanması, orta kulak efüzyonu, işitme ve soluma sorunları vb. bildirilmektedir. KBB uzmanları arasında MPS'ler konusunda farkındalı̆̆ıı artırılması çocuk doktorundan ziyade bir KBB uzmanına giden MPS'den kuşkulanılan hastalar için yaşam kurtarıcı bir çaba olacaktır. Mukopolisakkaridoz hastalarında kısa boyun nedeniyle trakeotomi yapmak zorlaşabilir. Ağız açmanın kısıtlanması nedeniyle tonsillektomi ve adsenoidektomi ameliyatlarından önce hastalar dikkatle değerlendirilmelidir. Anesteziden önce hava yolu sorunları değerlendirilmelidir. Tüm KBB uzmanlarının bu sorunların farkınnda olmaları konusunda dikkati çekilmelidir.

Anahtar sözcükler: Mukopolisakkaridozlar (MPS'ler), lizozom depo hastalıkları, kısa boyun, ağız açmanın kısıtlanması, hava yolu sorunları.

of GAG within the cells of various organs ultimately compromises their function. Clinical findings differ depending on the specific enzyme deficiency; therefore, clinical presentation and approaches to therapy are different for the various disease types.

Gönüldaş et al. ${ }^{[3]}$ reported that most MPS patients have airway obstruction and OSA due to adenotonsillar hyper-
Correspondence: Nuray Bayar Muluk, MD. Birlik Mahallesi, Zirvekent 2. Etap Sitesi, C-3 blok, No: 62/43, Çankaya, 06610, Ankara, Turkey.

e-mail: nbayarmuluk@yahoo.com, nurayb@hotmail.com

Received: October 17, 2014; Accepted: November 26, 2014
Online available at: www.jmedupdates.org doi:10.2399/jmu.2014003001 QR code: 
trophy. Most of these children benefit from adenotonsillectomy, after which OSA significantly resolves. They experience high recurrence rate after adenoidectomy; though this is not clinically problematic. They also suffer from conductive type hearing loss due to OME, which has to be treated with ventilation tube insertion. However, such operations are usually complicated by difficult endotracheal intubation and restricted mouth opening. Sometimes tracheotomy may be necessary. Tracheotomy is also highly complicated in MPS patients. GAG significantly accumulates in middle ear fluid and adenoid tissue; however, it appears not to accumulate in tonsillar tissue.

Typical facial features include coarse facial appearance, protruding or depressed frontal bone, wide eyebrows, depressed base of nose, wide nasal alae, thick lips, angled and hypoplastic mandible (micrognathia), macroglossy, distorted teeth, gingival hypertrophy and corneal opacities. Airway problems include obstructive sleep apnea (OSA), otitis media with effusion, sinusitis, frequent and recurrent respiratory infections, adenotonsillar hypertrophy, irregular nasal septum, turbinate hypertrophy, speech disorders, dyspnea, restricted temporomandibular joint motion, thickened pharyngeal wall, laryngeal abnormalities, tracheomalacia, tracheal stenosis and short neck. Otolaryngological involvement in MPS is due to accumulation of GAG in upper airway leading to obstruction and OSA, thus decreasing the quality of life of MPS patients..$^{[3-6]}$

Mouth opening status had restricted due to temporomandibular joint involvement in MPSs. MPS type III had significantly better mouth opening than other MPS types. MPS type VI had significantly worse mouth opening than other types. ${ }^{[3]}$ The middle ear fluid GAG level increased significantly in MPS patients. While $98.7 \%$ of MPS patients had hearing loss, $92.1 \%$ of the cases had conductive hearing loss. ${ }^{[3]}$

In this review paper, we reported otolaryngological problems (upper airway obstruction, obstructive sleep apnea, restriction of mouth opening, middle ear effusion, hearing and breathing problems, etc.) in patients with MPSs. The main aim of this paper is to ensure ENT doctors to aware of these types of diseases in their patients and sample for diagnosis (Fig. 1).

\section{Mucopolysaccharidoses (MPSs)}

Mucopolysaccharidoses (MPSs) are autosomal recessive, except for mucopolysaccharidosis type II, which is $\mathrm{X}$ linked. The mucopolysaccharidoses comprise a group of 7 metabolic disorders, known as mucopolysaccharidoses types I-VII. Mucopolysaccharidosis V is defined as a form of type I and is known as mucopolysaccharidosis IS. ${ }^{[1]}$

- Mucopolysaccharidosis type I and type V (IS)

- Mucopolysaccharidosis type II

- Mucopolysaccharidosis type III

- Mucopolysaccharidosis type IV

- Mucopolysaccharidosis type VI

- Mucopolysaccharidosis type VI

\section{Mucopolysaccharidosis Type I}

Hurler syndrome, the most severe form of mucopolysaccharidosis type I (MPS I), is a rare lysosomal storage disease. The overall incidence of MPS I is $0.99-1.99 / 100,000$ live births. Accumulation of glycosaminoglycans causes the progressive dysfunction of multiple organs. ${ }^{[7]}$ Historically, the most-to-least severe forms are as follows: Hurler syndrome, Hurler-Scheie syndrome, and Scheie syndrome.

L-iduronidase deficiency results in an inability of the lysosome to break down GAG, namely dermatan sulfate (DS) and heparan sulfate (HS). This process is essential for normal growth and homeostasis of tissues. In this disease, GAG progressively accumulates in the lysosomes, ultimately causing cell, tissue, and organ dysfunction by largely unknown pathophysiological mechanisms. The enzyme alpha-L-iduronidase deficiency causes an increase in the urinary excretion of dermatan sulfate (DS) and heparan sulfate (HS) in patients with MPS I.

Hurler syndrome is caused by mutation in the gene (IDUA) that encodes alpha-L-iduronidase on chromosome 4. Many different mutations have been found at this locus, including mutations that cause MPS IH (Hurler syndrome), MPS IS (Scheie syndrome), and MPS IH/S (Hurler-Scheie syndrome), among others. ${ }^{[1]}$

\section{Clinical manifestations}

Clinical manifestations of mucopolysaccharidosis type I (MPS I) show a chronic multisystemic and progressive course. ${ }^{[8]}$ The disease is highly heterogeneous, spanning a spectrum of severity. Children with Hurler syndrome appear normal at birth and develop the characteristic appearance over the first years of life. Symptoms across the types include facial dysmorphism, corneal clouding, hepatomegaly, valvular heart disease, obstructive airway disease, developmental delay, hearing loss, skeletal defor- 
mities ${ }^{\left[{ }^{19]}\right.}$ and joint stiffness. The neck is short, and odontoid hypoplasia is noted. Vertebral subluxation with cord compression can occur. Body hair may be coarser than usual, and the skin may be thicker.

For patients with the more severe form of the disease, the most typical symptoms occur early in life. These patients typically have numerous progressively debilitating symptoms, including mental retardation. Their lifespan expectancy is less than 10 years. ${ }^{[1]}$

\section{Otolaryngological manifestations in MPS I (Table 1)}

- Facial dysmorphism or coarse facial features: Coarsening of the facial features is usually the first sign detected. These features often first become apparent at age between 3-6 months and may become progressively more evident. The head is large with bulging frontal bones. The skull is often scaphocephalic secondary to premature closure of the metopic and sagittal sutures. Eyes may be widely spaced, and eye sockets may be shallow, causing the eyes to slightly protrude.

- The nasal bridge is depressed with broad nasal tip and anteverted nostrils.

- The cheeks are full. The lips are enlarged, and the mouth is usually held open, particularly after age 3 years.

- Chronic nasal discharge is present.

- The clinical presentation in less severe disease (MPS IS) may be limited to mild coarsening of facial features and prognathism. A large mouth with thick lips may develop. ${ }^{[1]}$

- Hearing loss ${ }^{[10]}$

Table 1. Otolaryngological manifestations in MPS I.

\begin{tabular}{|c|c|c|}
\hline \multicolumn{3}{|c|}{ Mucopolysaccharidosis type I } \\
\hline \multirow{4}{*}{ 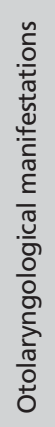 } & Head & $\begin{array}{l}\text { - Large head } \\
\text { - Bulging frontal bones }\end{array}$ \\
\hline & Nose & $\begin{array}{l}\text { - Depressed nasal bridge } \\
\text { - Anteverted nostrils } \\
\text { - Chronic nasal discharge }\end{array}$ \\
\hline & Face and mouth & $\begin{array}{l}\text { - Cheeks are full } \\
\text { - Enlarged lips } \\
\text { - Large mouth with thick lips } \\
\text { - Usually open mouth } \\
\text { - Coarsening of facial features and prognathism }\end{array}$ \\
\hline & Ear & - Hearing loss \\
\hline
\end{tabular}

\section{Mucopolysaccharidosis Type II}

Hunter syndrome or mucopolysaccharidosis type II (MPS II) is a MPS that is another member of inherited disorders of glycosaminoglycan (GAG) catabolism. ${ }^{[11]}$ Each MPS is caused by a deficiency in the activity of one of the distinct lysosomal enzymes required for the stepwise degradation of the GAGs dermatan sulfate, heparan sulfate, keratan sulfate, and chondroitin sulfate. ${ }^{[7,11]}$ In affected patients, undegraded or partially degraded GAG accumulates within lysosomes and is excreted in excess in the urine. ${ }^{[7,12]}$ It is the accumulation, or storage, of GAG within lysosomes that contributes to the signs and symptoms of these disorders. All MPSs are inherited in an autosomal recessive fashion, except for Hunter syndrome, which is $\mathrm{X}$-linked.

In the early 1900s, Gertrud Hurler and Charles Hunter first described patients with MPS, whose diseases now bear their names; subsequent MPSs have been assigned numbers and eponyms loosely associated with the chronology and origin of their report. MPS II was first described by Hunter in 1917. This X-linked disorder results from the deficiency of iduronate 2 sulfatase and subsequent accumulation of heparan and dermatan sulfate. In MPS II, due to the lack of iduronate 2 sulfatase (IDS), dermatan and heparan sulfate accumulate. ${ }^{[13]}$

The Hunter syndrome is distinct from the other mucopolysaccharidoses in that it is an X-linked disorder. The genetic locus has been mapped to Xq28. The gene defective in this disorder encodes IDS. ${ }^{[14,15]}$

The estimated incidence of MPS type II widely varies. The estimated incidence is one case per 34,000 in Israel, one case per 111,000 in British Columbia, and one case per 132,000 in the United Kingdom. ${ }^{[16-18]}$ Recent studies from Germany and the Netherlands report an incidence of one case in 140,000-330,000 live births, and 1.3 cases per 100,000 male births. ${ }^{[19,20]}$ The severe form of Hunter syndrome is typically diagnosed in children aged between 2-4 years. The attenuated form of Hunter syndrome may not be diagnosed until the teenage years or well into adulthood.

\section{Clinical manifestations}

Both types A and B MPS II have deficient IDS activity and are retained as terms useful in clinically describing the extremes of a disease spectrum. Children with classic type A MPS II have progressive coarsening of facial features, short stature, joint stiffness, hepatosplenomegaly, and hernias as common presenting signs and symptoms. Children with type A MPS II tend to have severe mental retardation and deafness. Other presentations include cerebral ven- 
tricular dilation and dysostosis multiplex. Skin findings include hypertrichosis, thickened skin, and multiple Mongolian spots. Children with type A and B MPS II may have papular skin lesions that are ivory in color and are located on the upper back and on the lateral upper arms and thighs. ${ }^{[1]}$

\section{Otolaryngological manifestations in MPS II (Table 2)}

- Frequent upper respiratory infections occur in most patients with Hunter syndrome.

- The enlarged tongue, hypertrophic adenoids and tonsils, and skeletal changes in the jaw and neck that limit the opening of the mouth ${ }^{[7,20,21]}$ all contribute to respiratory problems, as noted in "Respiratory System".

- Most patients have recurrent ear infections, and nearly all of them experience progressive hearing loss. ${ }^{[7,22-24]}$ The hearing loss is caused by both conductive and sensorineural deficits. ${ }^{[22,24]}$ Middle-ear effusion is recognized as an important contributor to hearing loss in patients with Hunter syndrome, and the evidence suggests that tympanomastoid abnormalities may also contribute to conductive hearing loss. ${ }^{[2]}$ Sensorineural hearing deficit has been commonly reported.

- The teeth have been described as peg shaped, and are irregularly shaped, and gingival tissue is hyperplastic and hypertrophic. ${ }^{[7,20,21]}$

- Respiratory obstruction is secondary to the accumulation of glycosaminoglycans in the cells of the trachea.

- Patients frequently have macrocephaly. The facial features of Hunter syndrome are coarse, but the children still have faces that resemble other family members.

- Patients with Hunter syndrome tend to have short necks.

Table 2. Otolaryngological manifestations in MPS II.

\begin{tabular}{|c|c|c|}
\hline \multicolumn{3}{|c|}{ Mucopolysaccharidosis type II } \\
\hline \multirow{4}{*}{ 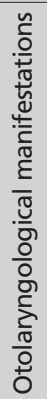 } & Respiratory & $\begin{array}{l}\text { - Respiratory obstruction (accumulation of } \\
\text { glycosaminoglycans in the cells of the trachea) }\end{array}$ \\
\hline & Head and neck & $\begin{array}{l}\text { - Macrocephaly } \\
\text { - Short neck }\end{array}$ \\
\hline & Face and mouth & $\begin{array}{l}\text { - Spaced teeth } \\
\text { - Enlarged tongue (more common in } \\
\text { children older than } 5 \text { years) } \\
\text { - Hypertrophic adenoids and tonsils }\end{array}$ \\
\hline & Ear & $\begin{array}{l}\text { - Hearing loss (often of mixed type but may be } \\
\text { either conductive or sensorineural) }\end{array}$ \\
\hline
\end{tabular}

- These patients may exhibit some oral manifestations of the disease with widely spaced teeth and an enlarged tongue. The enlarged tongue is more common in children older than 5 years. ${ }^{[1]}$

\section{Mucopolysaccharidosis Type III}

Mucopolysaccharidosis type III (MPS III/Sanfilippo syndrome) is an inherited metabolic disorder characterized by an absence/defect of lysosomal enzymes needed to break down glycosaminoglycans (GAGs). Accumulation of GAGs leads to progressive dysfunction of cells, tissues and organs. ${ }^{[25-27]}$ Incidence varies across countries with 1.21 per 100,000 babies affected in the UK. ${ }^{[25-27]}$ MPS III has three phases ${ }^{[28]}$ with the first phase (1-4 years) characterized by developmental delay, the second phase (4-10 years) by behavioral disturbance, including sleep difficulties, aggressive or destructive behaviors, hyperactivity and attention difficulties, and the third/end phase (10+ years) by progressive loss of skills (especially language), seizures, and problems with mobility and swallowing. The four subtypes of MPS III A-D correspond to variations in enzyme deficiency, with $\mathrm{A}$ and $\mathrm{B}$ being the most common and $\mathrm{D}$ the rarest. There is little clinical difference between subtypes, ${ }^{[28]}$ but A might show a more severe course ${ }^{[29]}$ and $\mathrm{C}$ a more attenuated course. ${ }^{[27,30]}$

Sanfilippo syndrome results from the deficiency or absence of 4 different enzymes that are necessary to degrade the GAG heparan sulfate. Each enzyme deficiency defines a different subtype of Sanfilippo syndrome, as follows: type IIIA (Sanfilippo A), type IIIB (Sanfilippo B), type IIIC (Sanfilippo C), and type IIID (Sanfilippo D). ${ }^{[31-34]}$

The clinical features of Sanfilippo syndrome, including the significant CNS component (brain and spinal cord), result from the progressive lysosomal accumulation of the GAG heparan sulfate. ${ }^{[35]}$

A prevalence of mucopolysaccharidosis IIIA was cited of one in 114,000 live births and the prevalence of mucopolysaccharidosis IIIB as one in 211,000 live births. Mucopolysaccharidosis IIIC and mucopolysaccharidosis IIID were much rarer, at one in 1,407,000 and one in $1,056,000$ live births, respectively. ${ }^{[3]}$

\section{Clinical manifestations}

The striking clinical findings of coarse facial features and skeletal abnormalities seen in the mucopolysaccharidoses are not as apparent in patients with mucopolysaccharidosis type III. Mild facial coarsening may be present, and the 
skeletal differences are typically subtle. Corneal clouding, as seen in the other mucopolysaccharidoses, is not usually present. However, classic clinical features are an abundance of coarse facial and body hair (hirsutism). ${ }^{[3]}$

\section{Otolaryngological manifestations in MPS III (Table 3)}

- Dense calvaria

- Joint stiffness

- Mild coarse facial features

- Synophrys: presence of abundant hair between the eyebrows

- Hearing loss with speech delay

- Sleep disturbances ${ }^{[27]}$

Table 3. Otolaryngological manifestations in MPS III.

\begin{tabular}{|c|c|c|}
\hline \multicolumn{3}{|c|}{ Mucopolysaccharidosis type III } \\
\hline \multirow{5}{*}{ 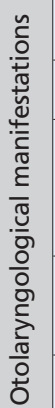 } & Head & - Dense calvaria \\
\hline & Joint & - Joint stiffness \\
\hline & Face and mouth & $\begin{array}{l}\text { - Mild coarse facial features } \\
\text { - Synophrys: presence of abundant } \\
\text { hair between the eyebrows }\end{array}$ \\
\hline & Ear & $\begin{array}{l}\text { - Hearing loss } \\
\text { - Speech delay }\end{array}$ \\
\hline & Sleep & - Sleep disturbances \\
\hline
\end{tabular}

\section{Mucopolysaccharidosis Type IV}

Morquio syndrome (mucopolysaccharidosis type IV) is a member of a group of inherited metabolic disorders collectively termed mucopolysaccharidoses. In 1929, Morquio, a pediatrician from Uruguay, and Brailsford, a radiologist from England, simultaneously described cases of what is now believed to be Morquio syndrome. Patients with Morquio syndrome (mucopolysaccharidosis type IV) can usually be clinically distinguished from patients with other MPSs because they do not have coarse facial features or mental retardation and they have additional skeletal manifestations derived from a unique spondyloepiphyseal dysplasia and ligamentous laxity. These skeletal manifestations include odontoid hypoplasia, a striking short trunk dwarfism, and genu valgus.

The enzyme deficiency in Morquio syndrome type IVA is galactosamine-6-sulfatase deficiency [i.e., $\mathrm{N}$-acetylgalactosamine-6-sulfate sulfatase deficiency]. The enzyme deficiency in Morquio syndrome type IVB was $\beta$-galactosidase deficiency. ${ }^{[1]}$

Compared with other patients who have MPS, those with Morquio syndrome (mucopolysaccharidosis type IV) tend to have greater spine involvement with scoliosis, kyphosis, and severe gibbus, as well as platyspondyly, rib flaring, pectus carinatum, and ligamentous laxity. Odontoid hypoplasia is the most critical skeletal feature to recognize in any patient with Morquio syndrome (mucopolysaccharidosis type IV). ${ }^{[38]}$

Morquio syndrome (mucopolysaccharidosis type IV), the degradation of KS is defective because of the deficiency of either $N$-acetyl-galactosamine-6-sulfate sulfatase (GALNS gene) in Morquio syndrome type IVA or $\beta$ galactosidase (GLB1 gene) in Morquio syndrome type IVB. Defective GALNS also affects the catabolism of chondroitin 6-sulfate. ${ }^{[1]}$

The estimated incidence of Morquio syndrome (mucopolysaccharidosis type IV) covers a wide range, including one case per 75,000 births in Northern Ireland, one case per 200,000 births in British Columbia, and one case per 263,157 births in Germany. ${ }^{[1]}$

\section{Clinical manifestations}

The most dramatic finding in patients with Morquio syndrome is their skeletal habitus. This includes short stature with short trunk, pectus carinatum, kyphosis, gibbus, scoliosis, genu valgus, flaring of the lower ribs, and joint abnormalities (joints range from hypermobile to contracted). Patients can alternatively have genu varus. ${ }^{[1]}$

\section{Otolaryngological manifestations in MPS IV (Table 4)}

- Mild coarsening of facial features

- Hearing difficulties,

- Carious teeth

- Thin tooth enamel ${ }^{[1]}$

Table 4. Otolaryngological manifestations in MPS IV.

\begin{tabular}{|c|c|c|}
\hline \multicolumn{3}{|c|}{ Mucopolysaccharidosis type IV } \\
\hline \multirow{3}{*}{ 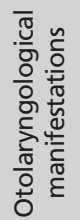 } & Face and mouth & $\begin{array}{l}\text { - Mild coarsening of } \\
\text { facial features }\end{array}$ \\
\hline & & $\begin{array}{l}\text { - Carious teeth } \\
\text { - Thin tooth enamel }\end{array}$ \\
\hline & Ear & - Hearing difficulties \\
\hline
\end{tabular}




\section{Mucopolysaccharidosis Type VI}

Mucopolysaccharidosis type VI (MPS VI), which is inherited as an autosomal recessive trait, results from the deficiency of $\mathrm{N}$-acetylgalactosamine-4-sulfatase (arylsulfatase B) activity and the lysosomal accumulation of dermatan sulfate. MPS VI is characterized by somatic features but not by mental retardation. MPS VI is characterized by progressive connective-tissue organ involvement that results from continuous accumulation of dermatan sulfate in the skeleton, heart valves, spleen, liver, lung, dura, and cornea.

Patients appear totally normal at birth and have accelerated growth in the first year, followed by deceleration and short stature later in childhood. The diagnosis is usually established during early childhood when organomegaly, corneal clouding, coarse features, enlarged tongue, frequent respiratory illness or otitis media, and joint stiffness are all apparent. Other complications include hearing loss, chronic respiratory tract infections, sleep apnea, pulmonary hypertension, hydrocephalus, rapid-onset blindness, and cardiac valve insufficiency or stenosis. ${ }^{[1]}$

An Australian survey reported an incidence rate of one per 248,000 births from 1980-1996. ${ }^{[3]}$ Reports from Germany, and northern Portugal noted birth incidences of one case per 432,610 births and one case per 238,095 births, respectively. ${ }^{[3,40]}$

\section{Clinical manifestations}

Progressive connective-tissue organ involvement that results from continuous storage of dermatan sulfate in the skeleton, heart valves, spleen, liver, lung, dura, and cornea are seen. Pulmonary hypertension, hydrocephalus, rapid-onset blindness, and cardiac valve insufficiency or stenosis are present. Hepatomegaly and splenomegaly are often present in patients with MPS VI. Umbilical and inguinal hernias are common. Growth may be normal for several years and may then stop, resulting in a final stature of $90-140 \mathrm{~cm}$. A short trunk with lumbar lordosis is typically present. Corneal opacities can be detected with slitlamp examination. Joint stiffness, claw-hand deformities appear in the first few years of life. Examination of the skin frequently reveals hirsutism. ${ }^{[1]}$

\section{Otolaryngological manifestations in MPS VI (Table 5) ${ }^{[1]}$}

- Macrocephaly

- Enlarged tongue

- Prominent forehead

- Possible coarse texture of hair

- Frequent respiratory infections

- Sleep apnea

- Otitis media
Table 5. Otolaryngological manifestations in MPS VI.

\begin{tabular}{|c|c|c|}
\hline \multicolumn{3}{|c|}{ Mucopolysaccharidosis type VI } \\
\hline \multirow{4}{*}{ 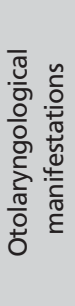 } & Head & $\begin{array}{l}\text { - Macrocephaly } \\
\text { - Prominent forehead }\end{array}$ \\
\hline & Face and mouth & $\begin{array}{l}\text { - Possible coarse texture of hair } \\
\text { - Enlarged tongue } \\
\text { - Sleep apnea }\end{array}$ \\
\hline & Ear & - Otitis media \\
\hline & Respiratory & - Frequent respiratory infections \\
\hline
\end{tabular}

\section{Mucopolysaccharidosis Type VII}

Mucopolysaccharidosis type VII (MPS VII) is a very rare lysosomal storage disease. MPS VII, traditionally known as Sly syndrome, was characterized for the first time in a patient with skeletal features similar to those observed in other patients with MPS. Sly syndrome is caused by deficiency of the enzyme $\beta$-glucuronidase. ${ }^{[41]}$ Historically, MPS VII is of interest because it was the first MPS (excluding the sex-linked gene for Hunter syndrome) for which the mutant gene was localized to chromosome 7 . MPS VII is extremely rare, and few cases have been described. ${ }^{[1]}$

MPS VII the molecular defect on the gene that encodes $\beta$-glucuronidase protein (GUSB) leads to deficiency of the enzyme $\beta$-glucuronidase. This enzyme is required for the breakdown of several GAGs, including dermatan sulfate (DS), heparan sulfate (HS), and chondroitin sulfate (CS]. ${ }^{[24]}$ Accumulation of DS, HS, and CS takes place in the lysosome of many systems and tissues, including the CNS. The pattern of urinary excretion of HS, DS, and/or CS may vary based on the subtype of MPS VII involved. ${ }^{[1]}$

\section{Clinical manifestations}

Mucopolysaccharidosis type VII (MPS VII) is a progressive, debilitating, and often life-threatening disease that affects multiple organ system. In most severe cases, the condition presents as hydrops fetalis. Neonatal jaundice may be present at birth. Dysostosis multiplex is also associated with the severe form of Sly syndrome. Coarse facial features with macrocephaly, hepatomegaly, hepatosplenomegaly, inguinal and umbilical hernias, and repeated upper respiratory infections may be observed. Severe growth retardation may be prominent during the first 2 years of life in patients with severe disease. ${ }^{[1]}$ 


\section{Otolaryngological manifestations in MPS VII} (Table 6)

- Coarse face, macrocephaly,

- Frontal prominence,

- Hirsutism

- Short neck

- Speech and language development delay due to moderate, nonprogressive mental retardation ${ }^{[42]}$

- Recurrent respiratory infections

- Hearing loss ${ }^{[1]}$

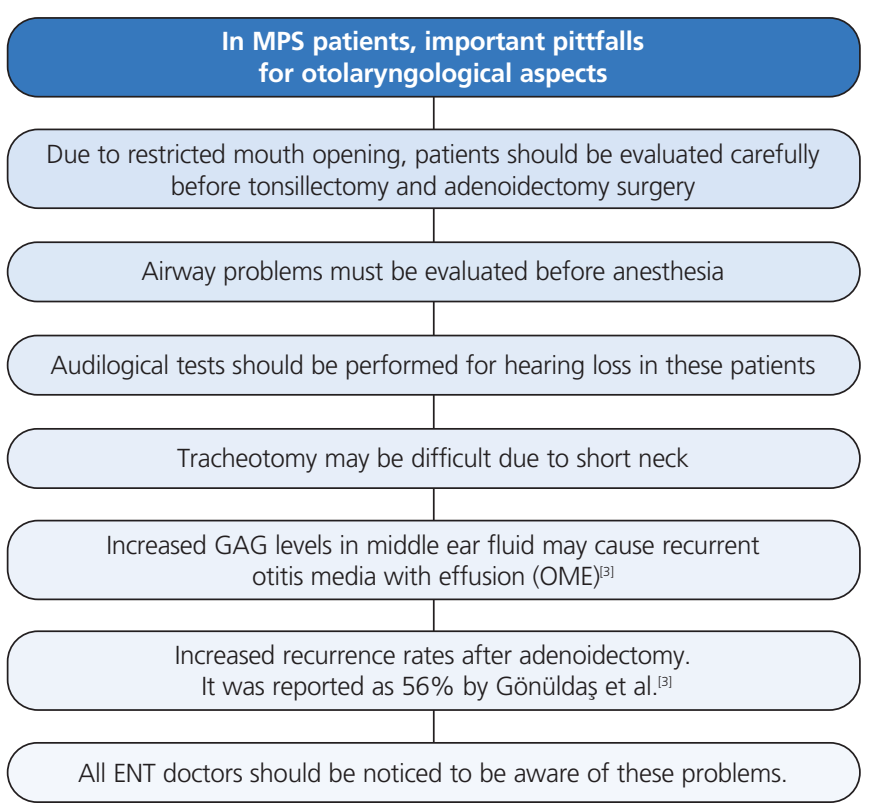

Fig. 1. Increasing awareness of MPS among ENT doctors will be a life saving attempt for some mild patients who admit an ENT doctor rather than a pediatrician.

\section{Acknowledgements}

"The preparation of this paper, including design and planning, was supported by the Continuous Education and Scientific Research Association.”

Conflict of Interest: No conflicts declared.

\section{References}

1. Baloghova J, Schwartz RA, Baranova Z, et al. Mucopolysaccharidoses Types I-VII. [cited 2014 Aug 21]. Available from: http://emedicine.medscape.com/article/1115193-overview.
Table 6. Otolaryngological manifestations in MPS VII.

\begin{tabular}{|c|c|c|}
\hline \multicolumn{3}{|c|}{ Mucopolysaccharidosis type VII } \\
\hline 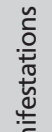 & Head and neck & $\begin{array}{l}\text { - Coarse face } \\
\text { - Macrocephaly } \\
\text { - Short neck }\end{array}$ \\
\hline$\frac{\tilde{\varepsilon}}{\frac{\tilde{\sigma}}{\pi}}$ & Face & $\begin{array}{l}\text { - Frontal prominence } \\
\text { - Hirsutism }\end{array}$ \\
\hline 음 & Respiratory & - Recurrent respiratory infections \\
\hline $\begin{array}{l}\frac{2}{0} \\
\frac{0}{0} \\
0\end{array}$ & Ear & $\begin{array}{l}\text { - Hearing loss } \\
\text { - Speech and language development delay }\end{array}$ \\
\hline
\end{tabular}

2. Yano S, Moseley K, Pavlova Z. Postmortem studies on a patient with mucopolysaccharidosis type I: Histopathological findings after one year of enzyme replacement therapy. J Inherit Metab Dis 2009;Suppl 1:S53-7.

3. Gönüldaş B, Yılmaz T, Sivri HS, et al. Mucopolysaccharidosis: otolaryngologic findings, obstructive sleep apnea and accumulation of glucosaminoglycans in lymphatic tissue of the upper airway. Int J Pediatr Otorhinolaryngol 2014;78:944-9.

4. Shih SL, Lee YJ, Lin SP, Sheu CY, Blickman JG. Airway changes in children with mucopolysaccharidoses. Acta Radiol 2002;43: 40-3.

5. Muenzer J. The mucopolysaccharidoses: a heterogeneous group of disorders with variable pediatric presentations. J Pediatr 2004; 144(5 Suppl.):S27-S34.

6. Simmons MA, Bruce IA, Penney S, Wraith E, Rothera MP. Otorhinolaryngological manifestations of the mucopolysaccharidoses. Int J Pediatr Otorhinolaryngol 2005;69:589-95.

7. Leroux S, Muller JB, Boutaric E, et al. Hurler syndrome: early diagnosis and treatment. Arch Pediatr 2014;21:501-6.

8. D'Aco K, Underhill L, Rangachari L, et al. Diagnosis and treatment trends in mucopolysaccharidosis I: findings from the MPS I Registry. Eur J Pediatr 2012;171:911-9.

9. Pastores GM. Musculoskeletal complications encountered in the lysosomal storage disorders. Best Pract Res Clin Rheumatol 2008; 22:937-47.

10. Kariya S, Schachern PA, Nishizaki K, Paparella MM, Cureoglu S. Inner ear changes in mucopolysaccharidosis type I/Hurler syndrome. Otol Neurotol 2012;33:1323-7.

11. Neufeld EF, Muenzer J. The mucopolysaccharidoses. In: Scriver CR, editor. The metabolic and molecular bases of inherited disease. New York, NY: McGraw-Hill; 2001. p. 3421-52.

12. Dorfman A, Lorincz AE. Occurence of urinary acid mucoploysaccharides in the Hurler syndrome. Proc Natl Acad Sci USA 1957; 43:443-6.

13. Brusius-Facchin AC, Abrahão L, Schwartz IV, et al. Extension of the molecular analysis to the promoter region of the iduronate 2sulfatase gene reveals genomic alterations in mucopolysaccharidosis type II patients with normal coding sequence. Gene 2013;526: $150-4$. 
14. Timms KM, Lu F, Shen Y, et al. $130 \mathrm{~kb}$ of DNA sequence reveals two new genes and a regional duplication distal to the human iduronate-2-sulfate sulfatase locus. Genome Res 1995;5:71-8.

15. Timms KM, Bondeson ML, Ansari-Lari MA, et al. Molecular and phenotypic variation in patients with severe Hunter syndrome. Hum Mol Genet 1997;6:479-86.

16. Lowry RB, Applegarth DA, Toone JR, MacDonald E, Thunem NY. An update on the frequency of mucopolysaccharide syndromes in British Columbia. Hum Genet 1990;85:389-90.

17. Schaap T, Bach G. Incidence of mucopolysaccharidoses in Israel: is Hunter disease a "Jewish disease"? Hum Genet 1980;56:221-3.

18. Young ID, Harper PS. Incidence of Hunter's syndrome. Hum Genet 1982;60:391-2.

19. Wraith JE, Beck M, Giugliani R, Clarke J, Martin R, Muenzer J. Initial report from the Hunter Outcome Survey. Genet Med 2008;10:508-16.

20. Hopkins R, Watson JA, Jones JH, Walker M. Two cases of Hunter's syndrome: the anaesthetic and operative difficulties in oral surgery. Br J Oral Surg 1973;10:286-99.

21. Downs AT, Crisp T, Ferretti G. Hunter's syndrome and oral manifestations: a review. Pediatr Dent 1995;17:98-100.

22. Young ID, Harper PS. The natural history of the severe form of Hunter's syndrome: a study based on 52 cases. Dev Med Child Neurol 1983;25:481-9.

23. Young ID, Harper PS. Mild form of Hunter's syndrome: clinical delineation based on 31 cases. Arch Dis Child 1982;57:828-36.

24. Peck JE. Hearing loss in Hunter's syndrome: mucopolysaccharidosis II. Ear Hear 1984;5:243-6.

25. Heron B, Mikaeloff Y, Froissart R, et al. Incidence and natural history of mucopolysaccharidosis type III in France and comparison with United Kingdom and Greece. Am J Med Genet A 2011;155A:58-68.

26. Meyer A, Kossow K, Gal A, et al. Scoring evaluation of the natural course of Mucopolysaccharidosis type IIIA (Sanfilippo syndrome type A). Pediatrics 2007;120:e1255-61.

27. Mahon LV, Lomax M, Grant S, et al. Assessment of sleep in children with mucopolysaccharidosis type III. PLoS One 2014;9(2):e84128.

28. Cleary MA, Wraith JE. Management of mucopolysaccharidosis type-III. Arch Dis Child 1993;69:403-6.

29. Van De Kamp JJP, Niermeijer MF, Von Figura K, Giesberts MAH. Genetic heterogeneity and clinical variability in the Sanfilippo syndrome types A B and C. Clin Genet 1981;20: 152-60.
30. Ruijter GJG, Valstar MJ, de Kamp JM, et al. Clinical and genetic spectrum of Sanfilippo type c (MPS IIIC) disease in the Netherlands. Mol Genet Metab 2008;93:104-11.

31. Zhang WM, Shi HP, Meng Y, Li BT, Qiu ZQ, Liu JT. Postnatal and prenatal diagnosis of mucopolysaccharidosis type III (Sanfilippo syndrome). [Article in Chinese] Zhonghua Er Ke Za Zhi 2008;46:407-10.

32. Fan X, Tkachyova I, Sinha A, Rigat B, Mahuran D. Characterization of the biosynthesis, processing and kinetic mechanism of action of the enzyme deficient in mucopolysaccharidosis IIIC. PLoS One 2011;6:e24951.

33. Ouesleti S, Brunel V, Ben Turkia H, et al. Molecular characterization of MPS IIIA, MPS IIIB and MPS IIIC in Tunisian patients. Clin Chim Acta 2011;412:2326-31.

34. Valstar MJ, Neijs S, Bruggenwirth HT, et al. Mucopolysaccharidosis type IIIA: clinical spectrum and genotype-phenotype correlations. Ann Neurol 2010;68:876-87.

35. Vitry S, Ausseil J, Hocquemiller M, Bigou S, Dos Santos Coura R, Heard JM. Enhanced degradation of synaptophysin by the proteasome in mucopolysaccharidosis type IIIB. Mol Cell Neurosci 2009;41:8-18.

36. Meikle PJ, Hopwood JJ, Clague AE, Carey WF. Prevalence of lysosomal storage disorders. JAMA 1999;281:249-54.

37. National Center for Biotechnology Information. Online Mendelian inheritance of man. [cited 2013 Jan 29]. Available from: http://www.ncbi.nlm.nih.gov/omim.

38. Montano AM, Tomatsu S, Gottesman GS, Smith M, Orii T. International Morquio A Registry: clinical manifestation and natural course of Morquio A disease. J Inherit Metab Dis 2007;30: 165-74.

39. Baehner F, Schmiedeskamp C, Krummenauer F, et al. Cumulative incidence rates of the mucopolysaccharidoses in Germany. J Inherit Metab Dis 2005;28:1011-7.

40. Pinto R, Caseiro C, Lemos M, et al. Prevalence of lysosomal storage diseases in Portugal. Eur J Hum Genet 2004;12:87-92.

41. Young RD, Liskova P, Pinali C, et al. Large proteoglycan complexes and disturbed collagen architecture in the corneal extracellular matrix of mucopolysaccharidosis type VII (Sly syndrome). Invest Ophthalmol Vis Sci 2011;52:6720-8.

42. Wallace SP, Prutting CA, Gerber SE. Degeneration of speech, language, and hearing in a patient with mucopolysaccharidosis VII. Int J Pediatr Otorhinolaryngol 1990;19:97-107.

This is an open access article distributed under the terms of the Creative Commons Attribution-NonCommercial-NoDerivs 3.0 Unported (CC BYNC-ND3.0) Licence (http://creativecommons.org/licenses/by-nc-nd/3.0/) which permits unrestricted noncommercial use, distribution, and reproduction in any medium, provided the original work is properly cited.

Please cite this article as: Cingi C, Bayar Muluk N, Hancı D, Şahin E, Acar M. Otolaryngological findings in mucopolysaccharidosis. J Med Updates 2014;4(3):122-129. 